\title{
Overproduction of N-Acetylneuraminic Acid (Sialic Acid) by Sialuria Fibroblasts
}

\author{
GEORGE H. THOMAS, LINDA W. REYNOLDS, AND CAROL S. MILLER
}

The John F. Kennedy Institute [G.H.T., L.W.R., C.S.M.]; and the Department of Pediatrics [G.H.T.] and the Department of Medicine [G.H.T.J, The Johns Hopkins University School of Medicine, Baltimore, Maryland

\begin{abstract}
Fibroblasts from the original sialuria patient are shown to contain high levels of free sialic acid, i.e., an average of 87 versus a normal average of $2 \mathrm{nmol} / \mathrm{mg}$ of protein. Gas liquid chromatography-mass spectrometry analysis confirmed that the accumulated material is $\mathrm{N}$ acetylneuraminic acid. Addition of $\mathrm{D}(+)$ glucosamine (0-5 $\mathrm{mM}$ ) to the media of these cells increased the intracellular free sialic acid concentrations from 74 to $137 \mathrm{nmol} / \mathrm{mg}$ protein. In contrast, normal cells treated in an identical manner maintained their normal free sialic acid level of less than $4 \mathrm{nmol} / \mathrm{mg}$ protein. Addition of $20 \mathrm{mM} \mathrm{N}$ acetylmannosamine in place of glucosamine resulted in a marked increase in free sialic acid in both the patient and the control, i.e., increases of 157 (from 95 to 252) and 120 (from 3 to 123 ) $\mathrm{nmol} / \mathrm{mg}$ protein, respectively. Finally, while normal cells in the presence of glucosamine accumulated high levels of uridine diphosphate $\mathrm{N}$-acetylhexosamine, the patient's cells accumulated much lower amounts of this compound. It is concluded that the elevated sialic acid level in sialuria is due, at least in part, to overproduction of free $\mathrm{N}$-acetylneuraminic acid. Indirect evidence is presented that this may result from either hyperactivity or increased levels of the enzyme (uridine diphosphate $\mathrm{N}$-acetylglucosamine 2-epimerase) that has been shown in other tissues to convert uridine diphosphate $\mathrm{N}$-acetylglucosamine to $\mathrm{N}$-acetylmannosamine. (Pediatr Res 19: 451-455, 1985)
\end{abstract}

\section{Abbreviations}

UDP, uridine diphosphate

CMP, cytidine monophosphate

In a series of papers dating from 1967 to the present, a number of investigators have described a male who excretes massive amounts ( $>5 \mathrm{~g}$ /day) of $\mathrm{N}$-acetylneuraminic acid (1-3). The clinical findings in this unique case include mental retardation, seizures, mildly dysmorphic features, hepatomegaly, and metabolic acidosis (1-3). Due to the striking biochemical alteration, the condition was given the designation "sialuria." McKusick (4) lists this disorder (Cat. no. 26990) as a possible, recessively inherited disorder.

Subsequent investigations carried out on urine from this patient revealed, in addition, excessive amounts of a number of potential precursors and/or metabolites of sialic acid (5-8). These

Received October 22, 1984; accepted December 31, 1984.

Supported by NIH Grant HD-10981.

Address Correspondence to Dr. George H. Thomas, Room 406, John F. Kennedy Institute, 707 North Broadway, Baltimore, MD 21205. include N-acetylmannosamine (7), N-acetylglucosamine (7), 2deoxy-2,3-dehydro- $\mathrm{N}$-acetylneuraminic acid (6), and 2-acetamidoglucal (5). We now report that cultured skin fibroblasts from the original sialuria patient exhibit altered sialic acid metabolism and/or storage, i.e. contain elevated levels of $\mathrm{N}$-acetylneuraminic acid.

Evidence is presented that indicates that the increased level of sialic acid in these cells is due, at least in part, to overproduction of $\mathrm{N}$-acetylneuraminic acid. Specifically, these data suggest that the excessive level of sialic acid could result from hyperactivity or increased levels of UDP-acetylglucosamine 2-epimerase responsible for the conversion of UDP-N-acetylglucosamine to $\mathrm{N}$ acetylmannosamine. It is speculated that the proposed increased epimerase activity could result from a lack of normal feedback inhibition of this enzyme.

\section{MATERIALS AND METHODS}

Fibroblasts from the original and only known sialuria patient were kindly provided to us by Professor J. P. Farriaux, Centre Hospitalier Regional de Lille, Lille, France. Both these and the control cells were held in liquid nitrogen until needed, at which time they were recultured $(9-11)$. As the only sialuria cell line available to us is infected with mycoplasma, control studies were carried out on normal cell lines both with and without infection with the same strain of mycoplasma. In all studies reported herein no detectable differences were found in these control cells and the normal data were combined.

Once reestablished, the cultures were maintained in Eagle's Minimum Essential Medium with Earles' salts (GIBCO Laboratories, Grand Island, NY) supplemented with fetal calf serum (final concentration $13 \%$ ), penicillin (final concentration $85 \mathrm{U} /$ $\mathrm{ml}$ ), streptomycin (final concentration $85 \mu \mathrm{g} / \mathrm{ml}$ ), and L-glutamine (final concentration $1.7 \mu \mathrm{mol} / \mathrm{ml}$ ).

For the loading tests the cells were subcultured into $490 \mathrm{~cm}^{2}$ roller bottles and incubated in the maintenance medium (see above) until just confluent, i.e. 3-4 days. At this time the medium was aspirated from the cells and replaced with the following: Eagle's Minimum Essential Medium with Earles' salts supplemented with heat inactivated, dialyzed fetal calf serum (final concentration $10 \%$ ) and L-glutamine (final concentration 2.0 $\mu \mathrm{mol} / \mathrm{ml}$ ). For the loading studies the fetal calf serum was heat inactivated $\left(52^{\circ} \mathrm{C}\right.$ for $30 \mathrm{~min}$ with shaking) and dialyzed (overnight against 2 liters of deionized water in the cold with one change after $2 \mathrm{~h}$ ). Glucosamine or $\mathrm{N}$-acetylmannosamine was dissolved in this medium to the final concentrations given in "Results."

Following incubation the cells were harvested, washed, and sonicated as previously described (12). Where indicated, the cell sonicates were precipitated with $10 \%$ trichloroacetic acid, centrifuged, the supernatant extracted with ethyl ether, and then neutralized with $\mathrm{NH}_{4} \mathrm{OH}$ as described elsewhere (12). 
UDP-N-acetylhexosamines and sialic acid was isolated from the neutralized trichloroacetic acid soluble fraction by ion exchange chromatography on $0.6 \times 4 \mathrm{~cm}$ columns of Dowex AG1X8 (200-400 mesh) in the formate form from Bio-Rad Laboratories, Richmond, CA $(12,13)$. Elution was carried out with a

\begin{tabular}{l|c|c|c|c} 
& $.01 \mathrm{M}$ & $1.0 \mathrm{M}$ & $4.0 \mathrm{M}$ & $4.0 \mathrm{M}$ Formic \\
Water & Formic & Formic & Formic & $4.0 \mathrm{M} \mathrm{NH}_{3}$ Formate
\end{tabular}

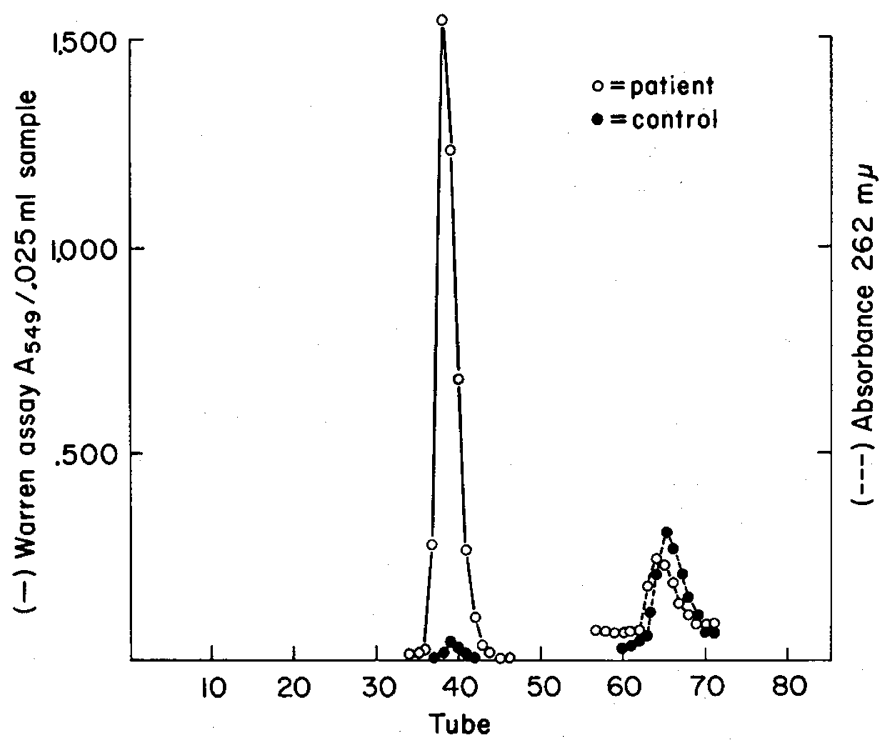

Fig. 1. Chromatographic pattern of thiobarbituric acid chromaphore and UDP-N-acetylhexosamines of cell sonicates of sialuria patient $(O)$ and control individual $(\Theta)$. Chromatographic separation was carried out by ion exchange on a $0.6 \times 4 \mathrm{~cm}$ column AG1-X8 (200-400 mesh) in the formate form. stepwise gradient of formic acid and/or $\mathrm{NH}_{4}$ formate according to a modification (12) of the method of Akamatsu et al. (14).

Detection and/or quantitation of the UDP-N-acetylhexosamines was based on absorbance at $262 \mathrm{~m} \mu$. The thiobarbituric acid-reactive material was measured according to a micromethod (15) of the Warren procedure (16). Gas liquid-mass spectrometry analysis of the isolated material was carried out as previously described (12). CMP-sialic acid was determined in cell sonicates after destruction of the existing free sialic acid with $2.7 \mathrm{M}$ sodium borohydride in $0.05 \mathrm{M}$ tris buffer according to a slight modification of the method of Kean and Roseman (17).

\section{RESULTS}

Biochemical analysis, carried out on sonicates of the patient's cells, showed them to contain a compound(s) that reacted with thiobarbituric acid before acid hydrolysis, i.e. noncovalently bound material capable of generating $\beta$-formylpyruvic acid, malonaldehyde, etc. Quantitation of this material on seven separate occasions over a 5-yr period, utilizing $\mathrm{N}$-acetylneuraminic acid as the standard, yielded an average concentration of $87 \mathrm{nmol} /$ mg protein, the range being 68-104. Normal fibroblasts cultured under the same conditions yielded an average value of 2.0 with a range of $0.6-3.9 \mathrm{nmol} /$ protein.

As the above values could include not only free sialic acid but also CMP-sialic acid, the contribution of the latter compound was determined (see "Materials and Methods"). This showed that the CMP-sialic acid concentration in the patient's cells was within the normal range, i.e. 4 versus a control range of $2-12 \mathrm{nmol} / \mathrm{mg}$ protein.

Following quantitation the thiobarbituric acid-reactive material was isolated from the sialuria patient's cells by ion-exchange chromatography. As shown in Figure 1 the reactive material was eluted from an AG1-X8 formate column with 1.0 molar formic acid in a manner identical to a pure sample of $\mathrm{N}$-acetylneuraminic acid. Sonicates of normal fibroblasts treated in an identical
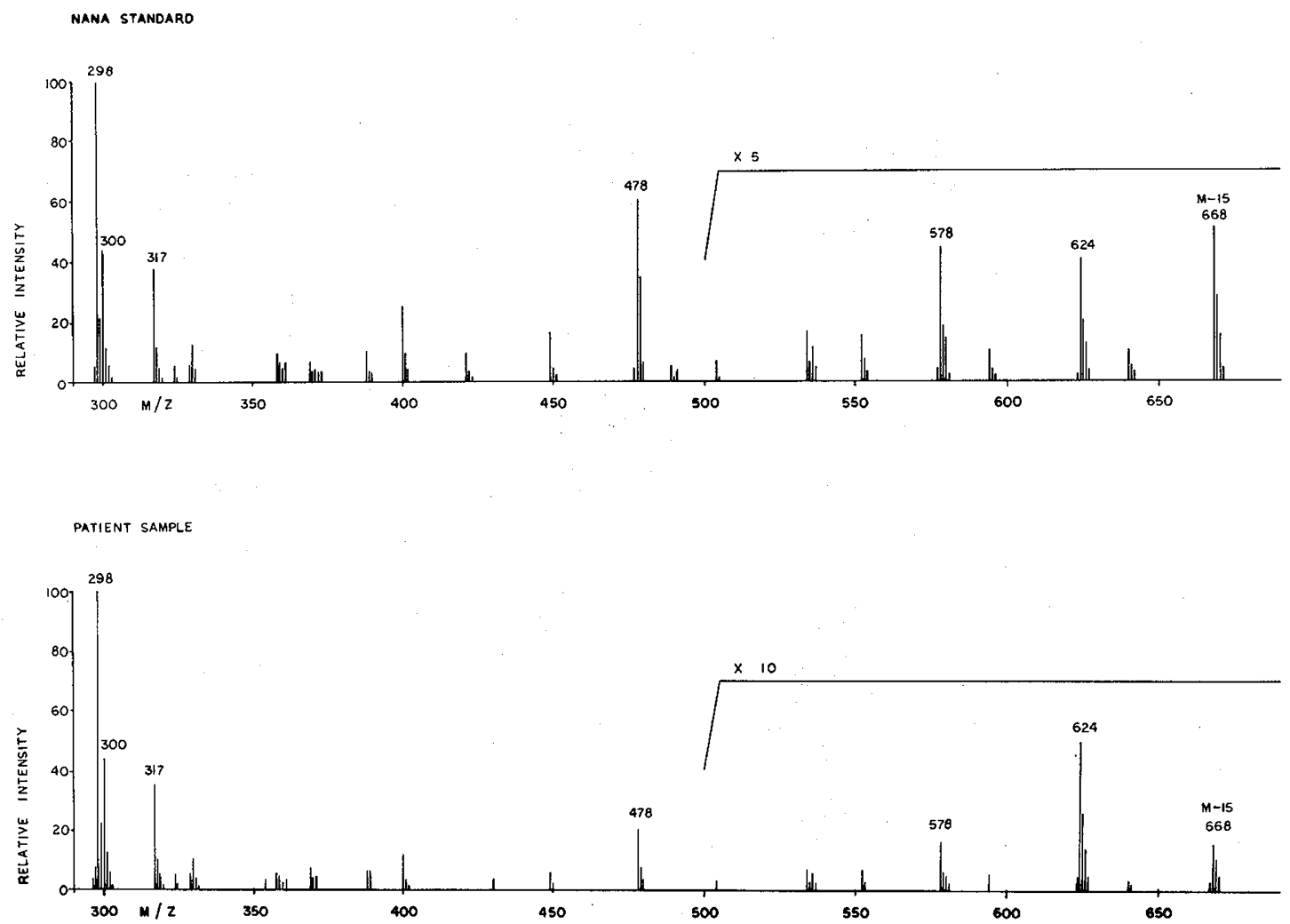

Fig. 2. Mass spectra of the trimethyl silyl derivative of the methyl ester of $\mathrm{N}$-acetylneuraminic acid and of the isolated "thiobarbituric acidpositive" material from the sialuria fibroblasts. 


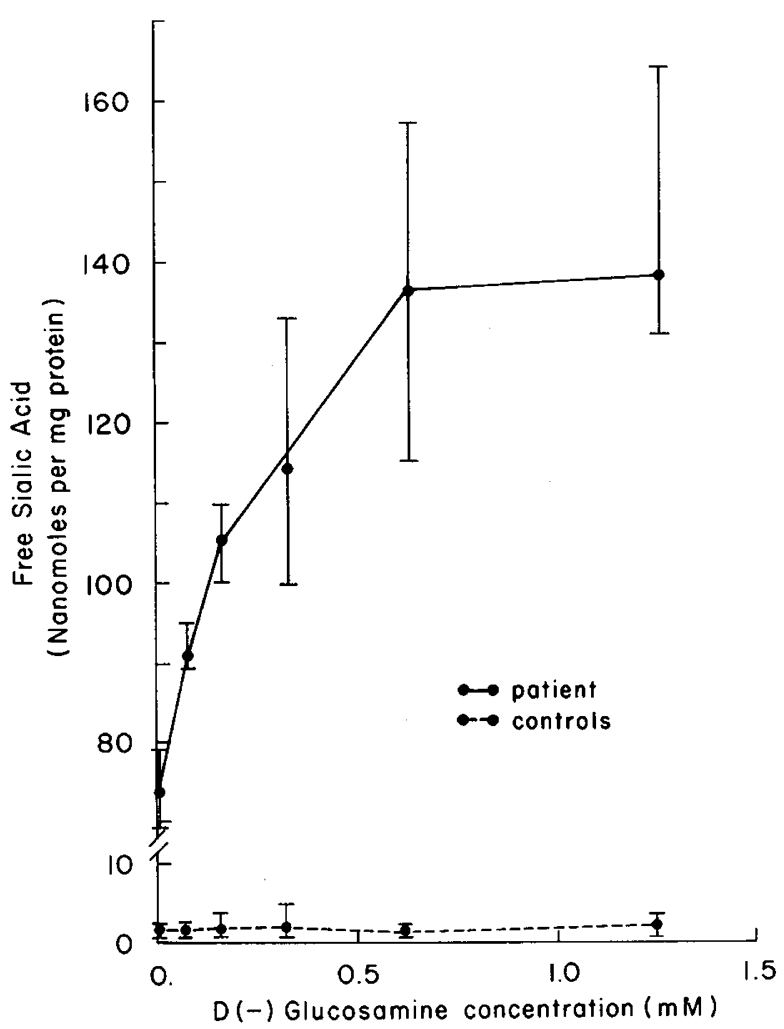

Fig. 3. Effect of extracellular glucosamine on the intracellular free sialic acid concentration. Confluent cell cultures were incubated for 72 $h$ as described in "Materials and Methods." The medium was supplemented with increasing concentrations of glucosamine. Initial levels were $0.08,0.16,0.31,0.63$, and $1.25 \mathrm{mM}$. The results represent the average and actual range of three experiments. The sialic acid was determined directly on cell sonicates as described in "Materials and Methods."

manner yielded similar material; however, at a much lower concentration (Fig. 1).

Gas-liquid chromatography mass spectrometry analysis of the trimethyl silylated methyl derivative of the material isolated from the patient's cells by ion-exchange chromatography showed the same mass fragments that characterize standard $\mathrm{N}$-acetylneuraminic acid (Fig. 2).

As shown in Figure 3 addition of glucosamine to the culture medium of the patient's fibroblasts increased the already elevated intracellular free sialic acid levels to still higher values. Thus, when incubated for $72 \mathrm{~h}$ in $0.61 \mathrm{mM}$ glucosamine (initial concentration) the free sialic acid concentration rose from an already abnormally high value of 74 to $137 \mathrm{nmol} / \mathrm{mg}$ protein (Fig. 3). Initial extracellular levels of glucosamine above $0.61 \mathrm{mM}$ had no additional effect on the measurable intracellular sialic acid pool(s) of the patient's cells.

In contrast to the sialuria cells, exposure of normal cells to increased concentrations of glucosamine yielded no detectable increase in their intracellular sialic acid concentration (Fig. 3). Thus, in the presence of from 0 to $5 \mathrm{mM}$ glucosamine for $72 \mathrm{~h}$, normal cells maintained baseline levels of free sialic acid, i.e. 1 to $2 \mathrm{nmol} / \mathrm{mg}$ protein.

As shown in Figure 4, however, addition of glucosamine to normal cells did result in an accumulation of the sialic acid precursor, UDP-N-acetylhexosamine. Thus, when incubated in media supplemented with an initial concentration of $0.61 \mathrm{mM}$ glucosamine for $72 \mathrm{~h}$, the intracellular concentration of UDP-Nacetylhexosamine rose from a baseline value of 39 to a final value of $95 \mathrm{nmol} / \mathrm{mg}$ protein. In contrast, the patient's cells went from an average of 26 to a final of $45 \mathrm{nmol}$ of UDP-N-acetylhexosamine per $\mathrm{mg}$ protein upon the addition of $0.61 \mathrm{mM} \mathrm{D}(+)$ glucosamine to the media. Also, as shown in Figure 4, increasing the extracellular $\mathrm{D}(+)$ glucosamine concentration from an initial level of 0.08-0.31 mM had little effect on the UDP-N-acetylhexosamine concentration of the patient's cells, i.e. increased the level by $3 \mathrm{nmol}$. This small change contrasts to the normal cells where a maximal and marked increase occurred, i.e. an increase of $29 \mathrm{nmol}$.

Finally, addition of $\mathrm{N}$-acetylmannosamine in place of glucosamine resulted in a marked accumulation of free sialic acid in both the normal cells and the patient's cells (Fig. 5). As shown in Figure 5 culturing the cells in $20 \mathrm{mM} \mathrm{N}$-acetylmannosamine (initial level) for $72 \mathrm{~h}$ increased the intracellular free sialic acid pool by 157 (from 95 to 252 ) nmol/mg protein in the patient's cells and by 120 (from 3 to 123 ) nmol/mg protein in the normal control cells.

\section{DISCUSSION}

The results presented herein demonstrate that cells from the original sialuria patient have 43.3 times more free sialic acid than normal cells, i.e. an average of 87 versus $2 \mathrm{nmol} / \mathrm{mg}$ protein. We conclude from this finding that these cultured fibroblasts express the fundamental biochemical defect responsible for the sialic acid abnormalities in sialuria.

The alterations in these cells could, in theory, arise from

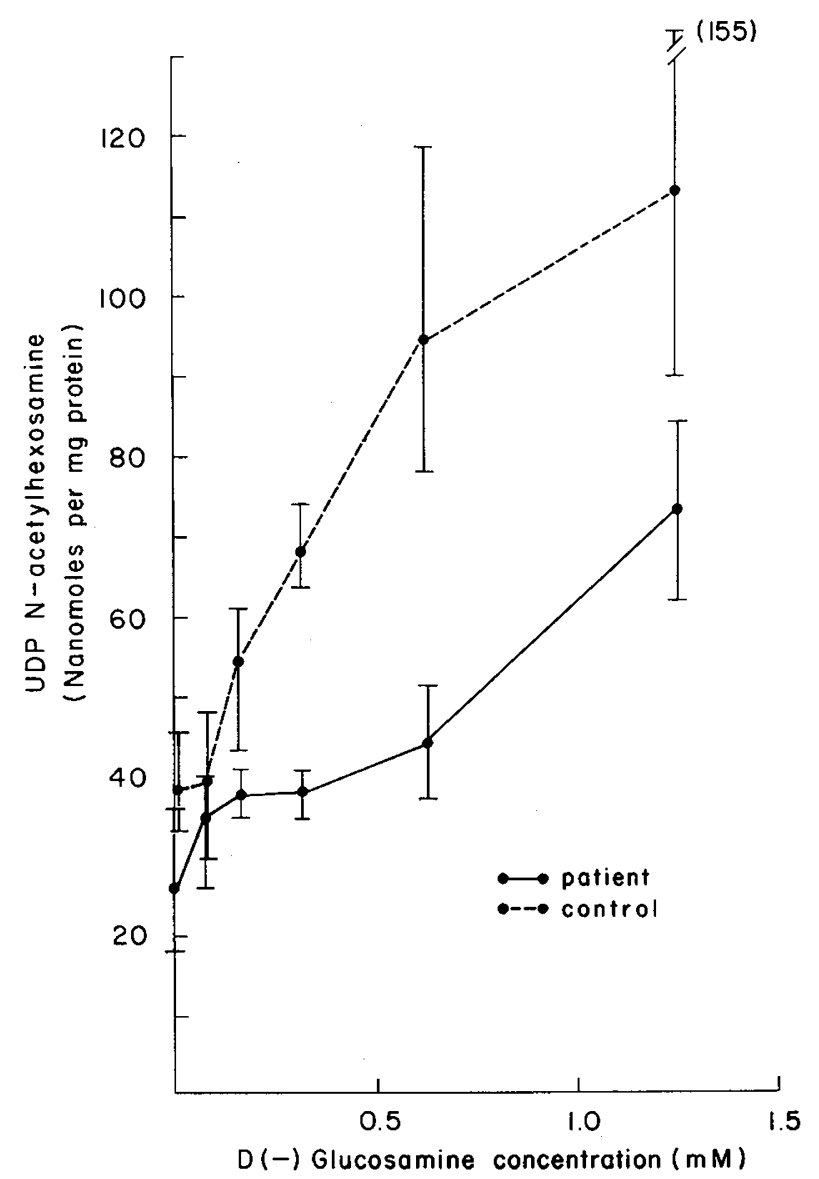

Fig. 4. Effect of extracellular $D(+)$ glucosamine on the intracellular UDP-N-acetylhexosamine concentration. Cell conditions are described in Figure 3. UDP-N-acetylhexosamine was isolated by ion exchange chromatography prior to quantitation by $262 \mathrm{~m} \mu$ absorbance. The results represent the average and the actual range of two (sialuria patient) and four (three different control lines) experiments. Initial glucosamine levels were $0.08,0.16,0.31,0.63$, and $1.25 \mathrm{mM}$. 
decreased utilization or catabolism of sialic acid. Obvious possibilities include a defect in the conversion of sialic acid to CMPsialic acid by CMP-N-acetylneuraminate synthetase (18), lack of cleavage of sialic acid to form pyruvate and N-acetyl-D-manno-

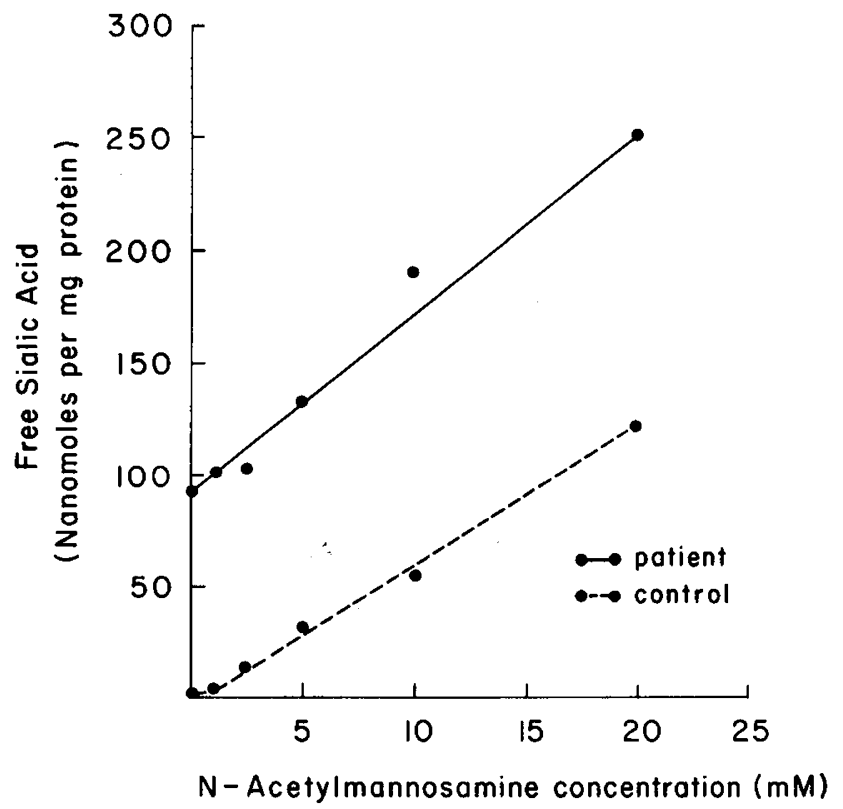

Fig. 5. Effect of extracellular $\mathrm{N}$-acetylmannosamine on the intracellular sialic acid concentration. Cell conditions are described in Figure 3. Cells were incubated for $72 \mathrm{~h}$ in the presence of increasing amounts of $\mathrm{N}$-acetylmannosamine and the sialic acid determined on cell sonicates. Initial $\mathrm{N}$-acetylmannosamine concentrations were $0,1.25,2.5,5.0,10$, and $20 \mathrm{mM}$. samine by sialic acid aldolase (19), absence of transfer of CMPsialic acid to glycoproteins and/or gangliosides by one or more sialyl transferases (20) or a defect in some, as yet, undiscovered catabolic pathway.

Alternatively, a maldistribution might result from a membrane defect causing either increased cellular or lysosomal storage similar to that found in cystinosis (21). A third hypothesis is that the sialic acid accumulation results, not from a metabolic or transport block, but rather from a disturbance in metabolic regulation. While inborn errors of metabolism due to overproduction appear to be rare, the magnitude and the types of the alterations in this patient suggest that this might be a likely possibility.

Investigations carried out over the past $20 \mathrm{yr}$ indicate that sialic acid is produced by a wide spectrum of tissue types and sources via the pathway shown in Figure $6(22,23)$. While incomplete, indirect evidence from both this and other laboratories suggest that cultured human cells may also produce sialic acid by a similar, if not identical, pathway. Direct proof, i.e. measurement of each enzyme step, is however lacking at this time. Several studies have shown that at least two steps of the pathway are subject to metabolic feedback regulation (24) in certain nonhuman tissues. Of possible relevance to this patient, both Kornfeld et al. (25) and Sommar and Ellis (26) have demonstrated in nonhuman tissues that CMP-sialic acid can regulate the biosynthesis of $\mathrm{N}$-acetylmannosamine by feedback inhibition of UDP-N-acetylglucosamine 2-epimerase (see Fig. 6). More recently, we have obtained evidence that the conversion of UDP-N-acetylglucosamine to the next intermediate is also at least, a rate-limiting step in human skin fibroblasts (Thomas GH, Reynolds LW, Miller CS, unpublished data). Specifically, the addition of glucosamine to the medium of normal human cells causes a marked expansion of the intracellular level of UDP$\mathrm{N}$-acetylhexosamine while having no effect on the end product, free sialic acid (Thomas GH, Reynolds LW, Miller CS, unpublished data). In contrast, the addition of the $\mathrm{N}$-acetylmannosa-

\section{Biosynthesis of CMP-N-acetylneuraminic Acid from Glucosamine}

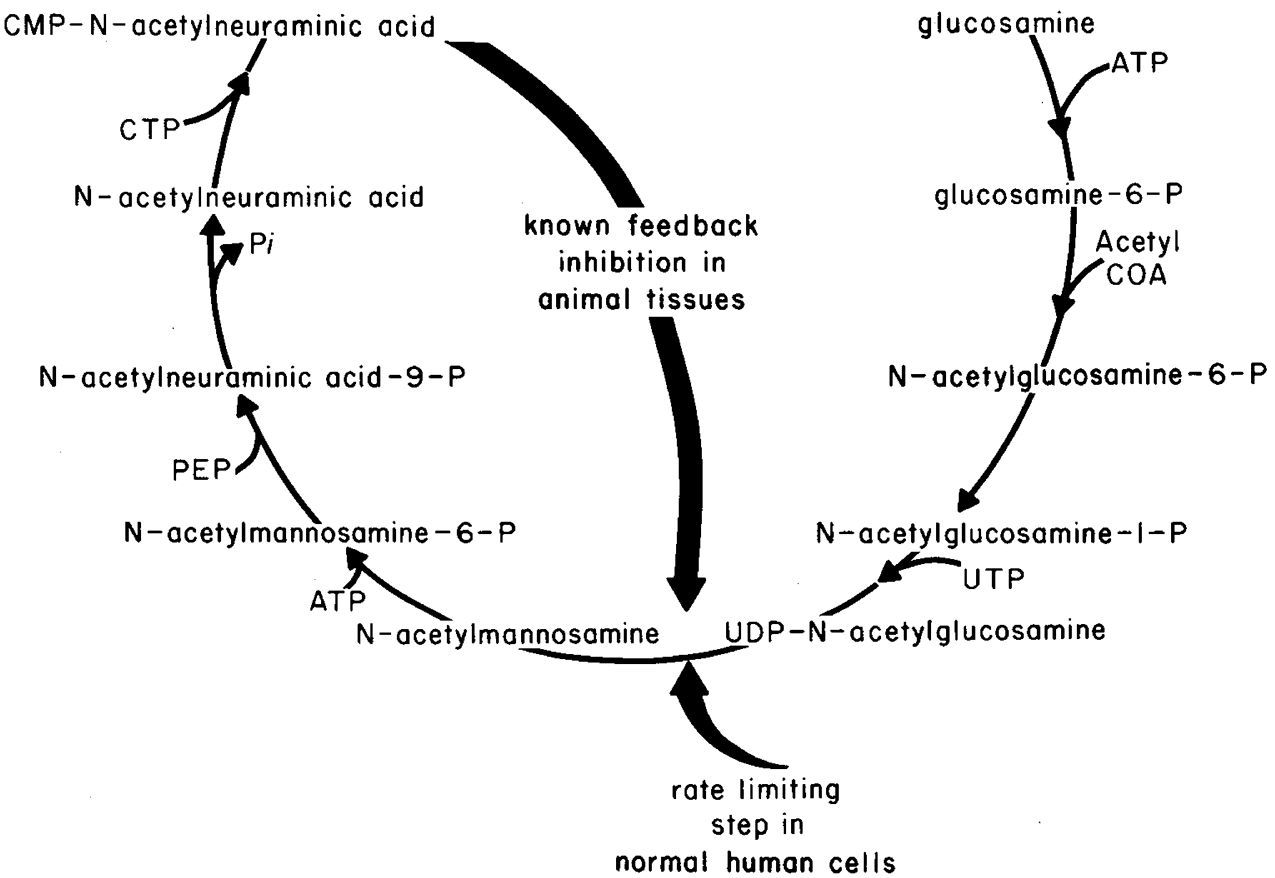

Fig. 6. Biosynthesis of sialic acid in mammalian tissues. Indirect evidence suggests, but has not yet proved, that sialic acid is formed in a similar manner in human skin fibroblasts. 
mine results in an accumulation of sialic acid (Thomas GH, Scocca J, Miller CS, Reynolds LW, unpublished data).

In contrast, as shown in Figures 3 and 4, addition of glucosamine to the patient's fibroblasts results in a reduced accumulation of the metabolic intermediate, UDP-N-acetylhexosamine, and a marked expansion of the already elevated sialic acid pool. When the medium is enriched with $\mathrm{N}$-acetylmannosamine in place of glucosamine both normal cells and the patient's cells accumulate free sialic acid; the increase was approximately the same (Fig. 5).

These data indicate that the rate-limiting step in normal cells, i.e. conversion of UDP-N-acetylglucosamine to N-acetylmannosamine (Fig. 6), is not rate limiting in the patient's cells. It is therefore concluded that the elevated level of free sialic acid in sialuria results from the overproduction of free sialic acid from one or more of its metabolic precursors. We speculate that this is due to hyperactivity or increased levels of UDP-acetylglucosamine 2-epimerase. This, however, is yet to be directly demonstrated.

Both Kamerling et al. (5) and more recently Cornfield and Schauer (24) have proposed that the basic defect in sialuria might be a lack of feedback regulation of UDP-acetylglucosamine 2epimerase. As noted previously, the enzymatic conversion of UDP-N-acetylglucosamine to N-acetylmannosamine by this enzyme has been shown in various animal tissues to be regulated by cytidine monophosphate $\mathrm{N}$-acetylneuraminic acid $(25,26)$. It was thus proposed, that a defect in this regulation could result in overproduction of sialic acid and/or CMP-sialic acid in sialuria.

Cornfield and Schauer (24) also proposed a second possible explanation, namely a block in the second step of the UDPacetylglucosamine 2-epimerase reaction which might result in the formation of 2-acetamidoglucal. It is suggested that the 2acetamidoglucal might then undergo nonenzymatic conversion to $\mathrm{N}$-acetylglucosamine followed by catalysis of the latter compound to $\mathrm{N}$-acetylmannosamine by a separate epimerase. If shown to be true this alternate pathway might bypass the regulated conversion of UDP-N-acetylglucosamine to N-acetylmannosamine thereby resulting in an overproduction of free sialic acid (24).

Overproduction of sialic acid could, in theory, also result from defective CMP-N-acetylneuraminic acid synthetase activity. This would result in not only an accumulation of the substrate, free sialic acid, but also a lack of the product CMP-sialic acid. Absence of or decreased levels of CMP-sialic acid would, in turn, result in a depression of the metabolic "down regulation" of the 2-epimerase with a resulted increase in sialic acid production.

Studies are now underway to determine if the overproduction of sialic acid demonstrated herein is, in fact, due to one of the possibilities discussed above.

Acknowledgments. Mass spectral determinations were carried out at the Middle Atlantic Mass Spectrometry Laboratory, a National Science Foundation shared instrumentation facility. We thank Dr. Jane Scocca and Ms. Sharon Pallante for their help with the gas chromatography-mass spectrometry study.

\section{REFERENCES}

1. Fontaine G, Biserte G, Montreuil J, Dupont A, Farriaux JP avec la collaboration de Strecker G, Spik G, Puvion E, Puvion-Dutilleul F, Sezille G, Picque' MT 1968 La sialurie: un trouble metabolique original. Helv Paediatr Acta 23(suppl XVII): 1-32

2. Fontaine G, Gaudier B, Biserte G, Montreuil J, Dupont A, Farriaux JP avec la collaboration de Strecker G, Spik G, Puvion E, Puvion-Dutilleul F, Sezille G 1967 Elimination urinaire permanente de'acide sialique libre chez un enfant de trois ans atteint de troubles cliniques divers. Pediatrie 22:705-709

3. Montreuil J, Biserte G, Strecker G, Spik G, Fontaine G, Farriaux JP 1968 Description d'un nouveau type de meliturie: la sialurie. Clin Chim Acta 21:61-69

4. McKusick VA 1978 Mendelian inheritance in Man, 5 th ed. The Johns Hopkins University Press, Baltimore

5. Kamerling JP, Strecker G, Farriaux JP, Dorland L, Haverkamp J, Vliegenthart JFG 1979 2-Acetamidoglucal, a new metabolite isolated from the urine of a patient with sialuria. Biochim Biophys Acta 583:403-408

6. Kamerling JP, Vliegenthart JFG, Schauer R, Strecker G, Montreuil J 1975 Isolation and identification of 2-deoxy-2,3-dehydro- $\mathrm{N}$-acetylneuraminic acid from the urine of a patient with sialuria. Eur J Biochem 56:253-258

7. Strecker G, Montreuil J $1971 \mathrm{~N}$-acetyl-glucosaminurie et $\mathrm{N}$-acetylmannosaminurie associees a'une sialurie. Clin Chim Acta 33:253

8. Strecker G, Montreuil J 1975 Dosage des glycoprotides totaux de l'urine et du serum d'enfants sains et d'un enfant sialurique. Clin Chim Acta 58:33-42

9. Lie KK, Thomas GH, Taylor HA, Sensenbrenner JA 1973 Anaylsis of N. acetyl $\beta$-D-glucosaminidase in mucolipidosis II (I-cell disease). Clin Chim Acta 45:243-248

10. Taylor HA, Thomas GH, Miller CS, Kelly TE, Siggers D 1973 Mucolipidosis III (pseudo-Hurler polydystrophy): cytological and ultrastructural observations of cultured fibroblast cells. Clin Genet 4:388-397

11. Thomas GH, Taylor HA, Reynolds LW, Miller CS 1973 Mucolipidosis III (pseudo-Hurler polydystrophy): multiple lysosomal enzyme abnormalities in serum and cultured fibroblast cells. Pediatr Res 7:751-756

12. Thomas GH, Scocca J, Libert J, Vamos E, Miller CS, Reynolds LW 1983 Alterations in cultured fibroblasts of sibs with an infantile form of a free (unbound) sialic acid storage disorder. Pediatr Res 17:307-312

13. Hurlbert RB, Schmitz H, Brummn AF, Potter VR 1954 Nucleotide metabolism. II. Chromatographic separation of acid soluble nucleotides. J Biol Chem 209:23-39

14. Akamatsu N, Nakajima H, Miyata S 1976 Glucosamine metabolism in regenerating rat liver. Biochem J 158:589-592

15. Thomas GH, Tiller GE Jr, Reynolds LW, Miller CS Bace JW 1976 Increased levels of sialic acid associated with a sialidase deficiency in I-cell disease (mucolipidosis II) fibroblasts. Biochem Biophys Res Commun 71:188-195

16. Warren L 1959 The thiobarbituric acid assay of sialic acids J Biol Chem 234:1971-1975

17. Kean EL, Roseman S 1966 CMP-sialic acid synthetase. Meth Enzymol 8:208215

18. Kean EL, Roseman S 1966 The sialic acids. X. Purification and properties of cytidine 5'monophosphosialic acid synthetase. J Biol Chem 241:5643-5650

19. Burnetti P, Jourdian GW, Roseman S 1962 The sialic acids. III Distribution and properties of animal $\mathrm{N}$-acetylneuraminic aldolase. $\mathrm{J}$ Biol Chem 237:2447-2453

20. Alhadeff JA, Cimino G, Janowsky A, O'Brien JS 1977 Human liver glycoprotein sialyltransferase. Biochim Biophys Acta 484:307-321

21. Gahl WA, Bashan N, Tietze F, Vernardini I, Schulman ID 1982 Cystine transport is defective in isolated leukocyte lysosomes from patients with cystinosis. Science 217:1263-1265

22. Rosenberg A, Schengrund C-L 1976 Biological Roles of Sialic Acid. Plenum Press, New York

23. Schauer R (ed) 1982 Sialic Acids, Chemistry, Metabolism, and Function. Cell Biology Monographs, Vol 10. Springer-Verlag, New York

24. Cornfield AP, Schauer R 1982 Metabolism of sialic acids. In: Schaueur R (ed) Cell Biology Monographs, Vol 10, Sialic Acids. Chemistry, Metabolism and Function. Springer-Verlag, New York, pp 195-261

25. Kornfeld S, Kornfeld R, Neufeld EF, O'Brien PJ 1964 The feedback control of sugar nucleotide biosynthesis in liver. Proc NAS 52:371-379

26. Sommar KM, Ellis DB 1972 Uridine diphosphate N-acetyl-D-glucosamine 2epimerase from rat liver. Catalytic and regulatory properties. Biochim Biophys Acta 268:581-589 